Quarterly Report on the Strontium Heat Source Development Program, Advanced Systems and Materials Production Division for October-December 1978

H. T. Fullam

January 1979

Prepared for the U.S. Department of Energy under Contract EY-76-C-06-1830

Pacific Northwest Laboratory Operated for the U.S. Department of Energy by Battelle Memorial Institute 


\title{
NOTICE
}

This report was prepared as an account of work sponsored by the United States: Government. Neither the United States nor the Department of Energy, nor any of their employees, nor any of their contractors, subcontractors, or their employees, makes any warranty, express or implied, or assumes any legal liability or responsibility for the accuracy, completeness or usefulness of any information, apparatus, product or process disclosed, or represents that its use would not infringe privately owned rights.

The views, opinions and conclusions contained in this report are those of the cantractor and do not necessarily represent those of the United States Government or the United States Department of Energy.

\author{
PACIFIC NORTHWEST LABORATORY \\ operated by \\ BATTELLE \\ for the \\ UNITED STATES DEPARTMENT OF ENERGY \\ Under Contract EY-76-C-06-1830
}

\begin{tabular}{|c|c|c|}
\hline \multicolumn{3}{|c|}{$\begin{array}{l}\text { Printed in the United States of Am } \\
\text { Available from } \\
\text { National Technical Information Ser } \\
\text { United States Department of Comm } \\
5285 \text { Port Royal Road } \\
\text { Springrield, Virginia } 22151\end{array}$} \\
\hline trice & Printed Copy & _: Micro \\
\hline & "Pages & $\begin{array}{l}\text { Nins } \\
\text { Selling Price }\end{array}$ \\
\hline & $001-025$ & $\$ 4.00$ \\
\hline & $026-050$ & 54.50 \\
\hline & $051-075$ & $\$ 5.25$ \\
\hline & $076-100$ & 3600 \\
\hline & $101-125$ & $\$ 6.50$ \\
\hline & $126-150$ & 57.25 \\
\hline & $151-175$ & 58.00 \\
\hline & $176-200$ & $\$ 9.00$ \\
\hline & $201-225$ & $\$ 9.25$ \\
\hline & $226-250$ & $\$ 9.50$ \\
\hline & $251-275$ & 510.75 \\
\hline & $276-300$ & $\$ 11.00$ \\
\hline
\end{tabular}


PNL $-1845-41$

UC -23

QUARTERLY REPORT ON THE STRONTIUM HEAT SOURCE DEVELOPMENT PROGRAM, ADVANCED SYSTEMS AND MATERIALS PRODUCTION DIVISION FOR OCTOBER-DECEMBER 1978

H. T. Fullam

January 1979

Prepared for the U.S. Department of Energy under Contract EY-76-C-06-1830

Pac if ic Northwest Laboratory Richland, Washington 99352 


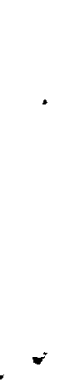

- 
The 20,000-hr compatibility tests using WESF ${ }^{90} \mathrm{SrF}_{2}$ have been completed. The test capsules were shipped to Oak Ridge National Laboratory (ORNL) and metallographic examination of the test specimens is now underway.

Work continues on the final design of the prototype outer capsule. Efforts are underway to obtain the Hastelloy $S$ and Hastelloy C-4 to be used in fabricating the prototype outer capsules. Puncture testing of the stand-in steel outer capsule was carried out without damage to the capsule. Effort continued on impact testing of the stand-in capsule.

Tests to measure the oxidation rates of Hastelloy S and Hastelloy C-4 in air at $600^{\circ}$ to $800^{\circ} \mathrm{C}$ are continuing. Short-term test data for up to $2500-\mathrm{hr}$ exposure indicated that oxidation of the two alloys adhered to parabolic rate relationships. Specimens oxidized for $5000 \mathrm{hr}$ and $7500 \mathrm{hr}$ exhibited erratic oxidation behavior, and the average oxidation rates were less than predicted by parabolic rate equations developed from the short-term rate data. Room-temperature tension testing of specimens oxidized in air at $600^{\circ}$ to $800^{\circ} \mathrm{C}$ for up to $7500 \mathrm{hr}$ indicated that oxidation had no significant effect upon the roomtemperature tensile properties of the two alloys. 
. 
SUMMARY • • • • • • • • • • • • • • • • • • • • • • • • • • • •

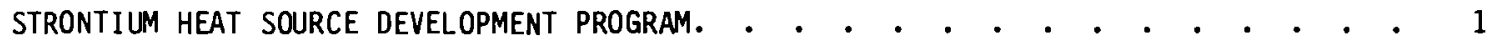

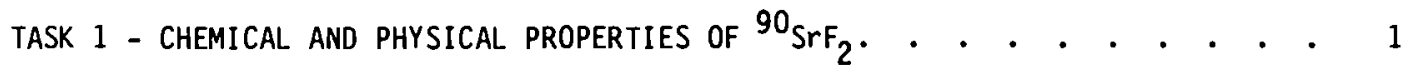

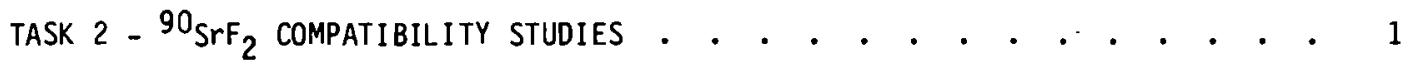

TASK 3 - CAPSULE QUALIFICATION AND LICENSING • • • • • • • • • • • •

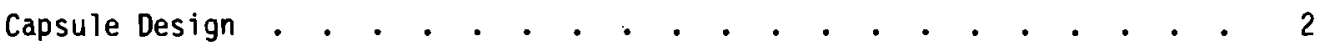

Oxidation of Hastelloy S and Hastelloy C-4 . . . . . . . . . . . 6

Seawater Corrosion of Hastelloy S and Hastelloy C-4 . . . . . . . 8 


\section{LIST OF FIGURES}

1 Hastelloy $\mathrm{C}-276 \mathrm{Spec}$ imens Exposed to Nonradioactive SrF 2 for

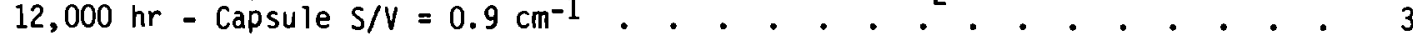

2 Haynes Alloy $25 \mathrm{Spec}$ imens Exposed to Nonradioactive $\mathrm{SrF}_{2}$ for

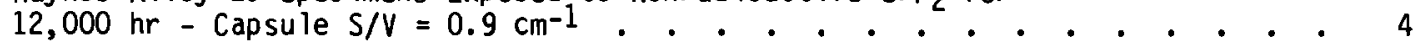

3 TZM Specimens Exposed to Nonradioactive $\mathrm{SrF}_{2}$ for $12,000 \mathrm{hr}$

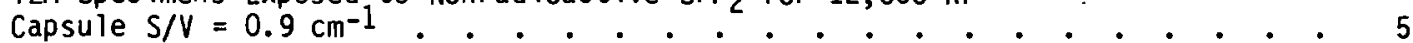

4 Sketch Showing Locations of the Three Puncture Tests on the

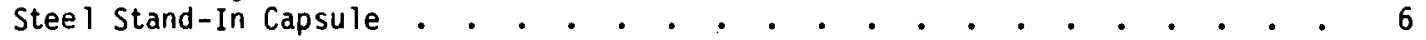

5 Photograph of a 30-Foot Drop Test of an AISI-1018 Steel

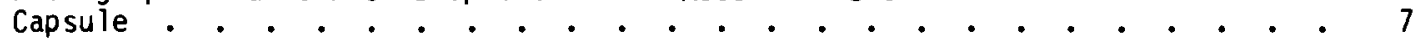

6 Oxidation of Hastelloy $S$ in Air in a Muffle Furnace. . . . . . . . . $\quad 8$

7 0xidation of Hastelloy C-4 in Air in a Muffle Furnace . . . . . . . . . 8

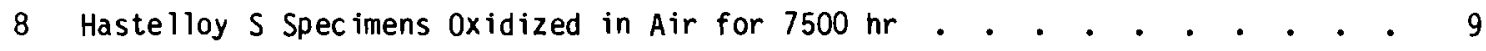

9 Hastelloy C-4 Specimens 0xidized in Air for $7500 \mathrm{hr}$. . . . . . . . . $\quad 10$

10 Room-Temperature Tensile Properties of Hastelloy $S$ Aged in Air or Vacuum at $600^{\circ} \mathrm{C}$. . . . . . . . . . . . . . . . . . . 12

11 Room-Temperature Tensile Properties of Hastelloy $S$ Aged in Air or Vacuum at $700^{\circ} \mathrm{C}$. . . . . . . . . . . . . . . . . 13

12 Room-Temperature Tensile Properties of Hastelloy $S$ Aged in Air or Vacuum at $800^{\circ} \mathrm{C}$. . . . . . . . . . . . . . . . . . . 14

13 Room-Temperature Tensile Properties of Hastelloy C-4 Aged in

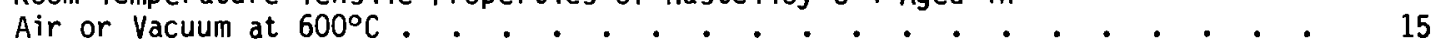

14 Room-Temperature Tensile Properties of Hastelloy C-4 Aged in Air or Vacuum at $700^{\circ} \mathrm{C}$. . . . . . . . . . . . . . . . . . 16

15 Room-Temperature Tensile Properties of Hastelloy C-4 Aged in

16 Hastelloy $S$ and Hastelloy $C-4$ Test Coupons, Including Tensile Specimens, Exposed to Flowing Natural Seawater for $5000 \mathrm{hr}$. . . . . . . . . . . . . . . . . . . . . . . 18

17 Corrosion of Hastelloy $S$ in Flowing Natural Seawater at

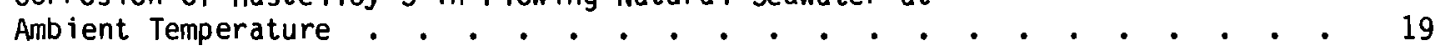

18 Corrosion of Hastelloy $\mathrm{C}-4$ in Flowing Natural Seawater at Ambient Temperature . . . . . . . . . . . . . . . . . . 
1 Est imated Attack of Metal Specimens Exposed to Nonradioactive

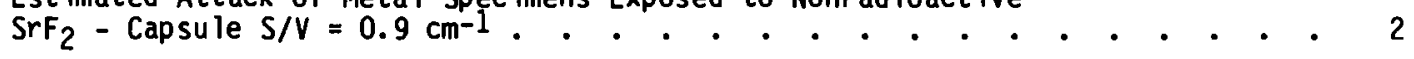

2 Room-Temperature Tensile Properties of Hastelloy S Specimens Aged in Air or Vacuum at $600^{\circ} \mathrm{C}, 700^{\circ} \mathrm{C}$, and $800^{\circ} \mathrm{C}$. . . . . . . . . . . 11

3 Room-Temperature Tensile Properties of Hastelloy $\mathrm{C}-4$ Specimens .
Aged in Air or Vacuum at $600^{\circ} \mathrm{C}, 700^{\circ} \mathrm{C}$, and $800^{\circ} \mathrm{C} . \quad . \quad . \quad . \quad . \quad . \quad . \quad . \quad . \quad 11$

4 Room-Temperature Tensile Properties of Hastelloy $S$ and Haste lloy C-4 Specimens Exposed to Flowing. Natural Seawater at Ambient Temperature

$\cdot \cdot \cdot \cdot \cdot$ 


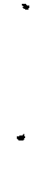




\section{STRONTIUM HEAT SOURCE DEVELOPMENT PROGRAM}

H. H. Van Tuy 1, Program Manager

H. T. Fullam, Principal Investigator

D. G. Atteridge

F. A. Simonen

At Hanford, strontium is separated from the high-level waste, converted to the fluoride, and doubly encapsulated in sma11, high-integrity containers for subsequent long-term storage. The fluoride conversion, encapsulation, and storage take place in the Waste Encapsulation and Storage Facilities (WESF). The encapsulated strontium fluoride represents an economical source of $90 \mathrm{Sr}$ if the WESF capsule can be licensed for heat source applications under anticipated use conditions. The objectives of this program are to obtain the data needed to license ${ }^{90} \mathrm{SrF}_{2}$ heat sources, and specifically the WESF ${ }^{90} \mathrm{SrF}_{2}$ capsules. The information needed for licensing can be divided into three general task areas:

Task 1 - Chemical and Physical Properties of ${ }^{90} \mathrm{SrF}_{2}$

Task $2-{ }^{90} \mathrm{SrF}_{2}$ Compatibility Studies

Task 3 - Capsule Qualification and Licensing

Efforts are proceeding concurrently on all three tasks to obtain the required information.

TASK 1 - CHEMICAL AND PHYSICAL PROPERTIES OF ${ }^{90} \mathrm{SrF}_{2}$ (H. T. Fullam)

No activity this quarter.

TASK $2-{ }^{90} \mathrm{SrF}_{2}$ COMPATIBILITY STUDIES (H. T. Fullam)

All of the remaining compatibility tests are proceeding as scheduled. The capsules from the $20,000-h r$ tests with ${ }^{90} \mathrm{SrF}_{2}$ were shipped to the Oak Ridge National Laboratory (ORNL) for analysis. The capsules have been sectioned, and metallographic examination of the test specimens is underway.

Supplemental compatibility tests with nonradioactive $\mathrm{SrF}_{2}$ are underway using test capsules having a metal surface-to-SrF 2 volume ratio (S/V) of $0.9 \mathrm{~cm}^{-1}$ (the WESF ${ }^{90} \mathrm{SrF}_{2}$ storage capsule has an $\mathrm{S} / \mathrm{V}$ of $0.87 \mathrm{~cm}^{-1}$ ). The $S r F_{2}$ used in the tests contains impurities similar to those found in WESF ${ }^{90} \mathrm{SrF}_{2}$. The $12,000-\mathrm{hr}$ tests have been completed, and the metal specimens examined. The results obtained are presented in Table 1, and data from the 1000- and 6000-hr tests are also included for comparison purposes. Photomicrographs of the test specimens are shown in Figures 1, 2 and 3 . Evaluation of the test results show that, overall, attack of the specimens did not increase significantly as the exposure time was increased from 6000 to 12,000 hours. This confirms the results obtained with nonradioactive $S_{2} F_{2}$ test capsules having larger $S / V$ values (i.e., $\left.2.5,4.5 \mathrm{~cm}^{-1}\right)$. The results provide additional evidence that metal attack is due primarily to impurities in the $\mathrm{SrF}_{2}$ and that the impurities are consumed in a relatively short period of time. 
TABLE 1. Estimated Attack of Metal $\mathrm{Spec}$ imens Exposed to Nonradioactive $\mathrm{SrF}_{2}(\mathrm{a})$ Capsule $S / V=0.9 \mathrm{~cm}^{-1}$

\begin{tabular}{|c|c|c|c|c|c|c|c|}
\hline \multirow[b]{2}{*}{ Material } & \multirow[b]{2}{*}{$\begin{array}{c}\text { Temperature, } \\
{ }^{\circ} \mathrm{C} \\
\end{array}$} & \multicolumn{6}{|c|}{ Depth of Metal Affected, mils (b) } \\
\hline & & $1,000 \mathrm{hr}$ & $\begin{array}{c}\text { Chemical Att } \\
6,000 \mathrm{hr}\end{array}$ & $12,000 \mathrm{hr}$ & $\begin{array}{l}\text { Chang } \\
1,000 \mathrm{hr} \\
\end{array}$ & $\begin{array}{l}\text { in Microst } \\
6,000 \mathrm{hr}\end{array}$ & $\frac{\text { ructure }}{12,000 \mathrm{hr}}$ \\
\hline \multirow[t]{3}{*}{ Hastelloy C-276 } & 600 & 1 & 6 & 3 & 4 & 6 & 6 \\
\hline & 800 & 10 & 10 & 7 & 15 & 15 & 8 \\
\hline & 1000 & 4 & 8 & 7 & 6 & 12 & 12 \\
\hline \multirow[t]{3}{*}{ Haynes Alloy 25} & 600 & 1 & 3 & 2 & 2 & 3 & 0 \\
\hline & 800 & 1 & 5 & 4 & 2 & 17 & 5 \\
\hline & 1000 & 3 & 12 & 14 & 2 & 15 & 16 \\
\hline \multirow[t]{3}{*}{ TZM } & 600 & 1 & 2 & 2 & 0 & 0 & 0 \\
\hline & 800 & 1 & 4 & 2 & 0 & 0 & 0 \\
\hline & 1000 & 1 & 1 & 1 & 0 & 0 & 2 \\
\hline
\end{tabular}

(a) $\mathrm{SrF}_{2}$ contained impurities approximating those found in WESF ${ }^{90} \mathrm{SrF}_{2}$.

(b) Est imated from photomicrographs.

TASK 3 - CAPSULE QUALIFICATION AND LICENSING (D. G. Atteridge)

Capsule Design

Evaluation of the proposed outer capsule design continued during this quarter. Work was concentrated on impact and puncture testing of the stand-in AISI-1018 steel capsules. The puncture testing was completed this quarter, along with the evaluation of the drop test capsule alignment and release mechanism and the photographic drop event recording equipment.

The 0.5-in. wall thickness stand-in steel capsule used in the puncture testing was the same capsule that withstood the 1000-bar hydrostatic test reported on in the previous quarterly report. The capsule was puncture tested at the three locations shown in Figure 4: at the middle of the capsule, at the inner edge of the capsule lid, and at the inner edge of the weld. The three puncture drops left slight indentations on the capsule surface but did not puncture the capsules, as was evident from visual inspection and substantiated by subsequent helium leak checking.

Two sets of capsule drops were made from our 30-foot drop tower this quarter in order to evaluate different photographic equipment. We desired multiple pictures of the last eight feet of the drop with sufficient resolution capability to allow measurement of the off-vertical capsule axis angle at impact. A high-speed $35 \mathrm{~mm}$ camera was used to record one set of test drops, while a high-speed $16 \mathrm{~mm}$ movie camera was used to record the second set of tests. It was found that the $35 \mathrm{~mm}$ camera gave sharp photographs, as shown in Figure 5, but was not fast enough to assure capture of more than one photograph during the last eight feet of the drop. The movie camera was able to capture multiple photographs of the drop event but gave relatively poor capsule resolution when individual frames were blown up to 8 -in. $\times 10$-in. prints. Nevertheless, it is felt that the $16 \mathrm{~mm}$ film yields 
$600^{\circ} \mathrm{C}$
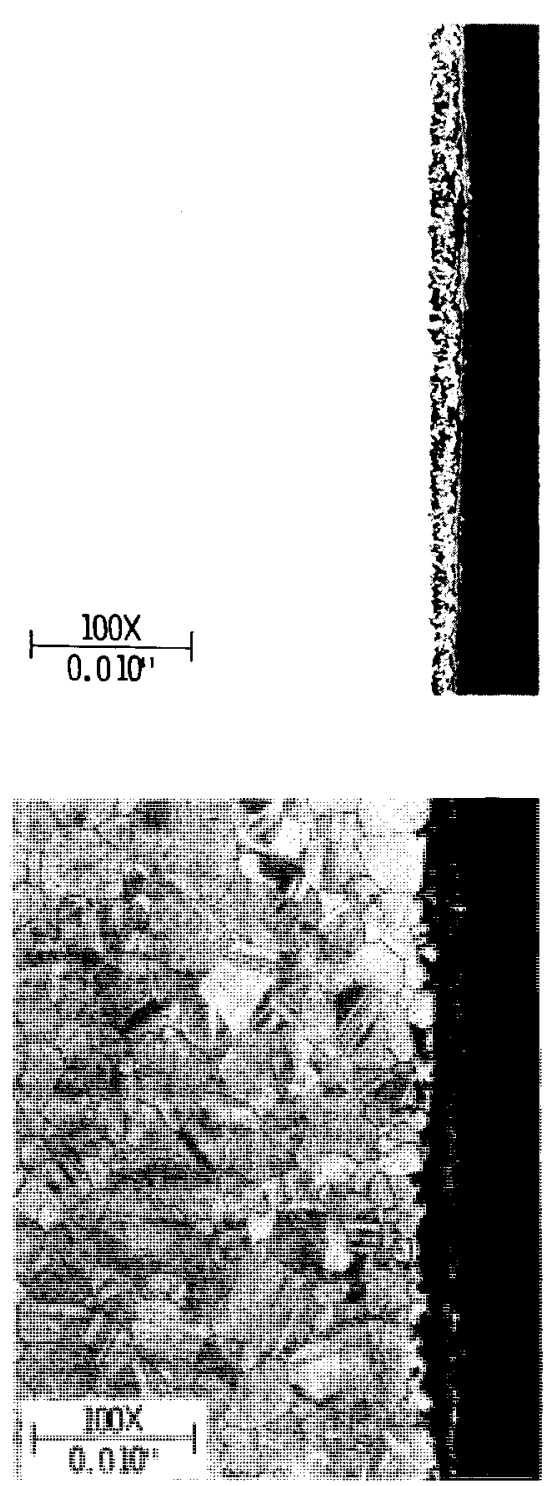

$800^{\circ} \mathrm{C}$

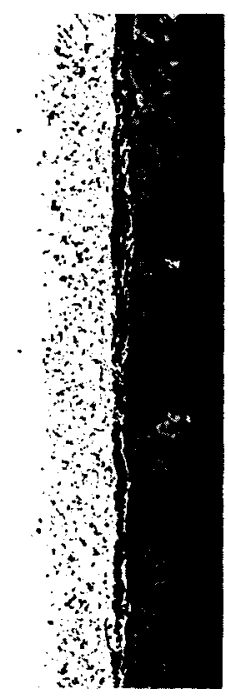

$\frac{100 x}{0.010^{11}}$

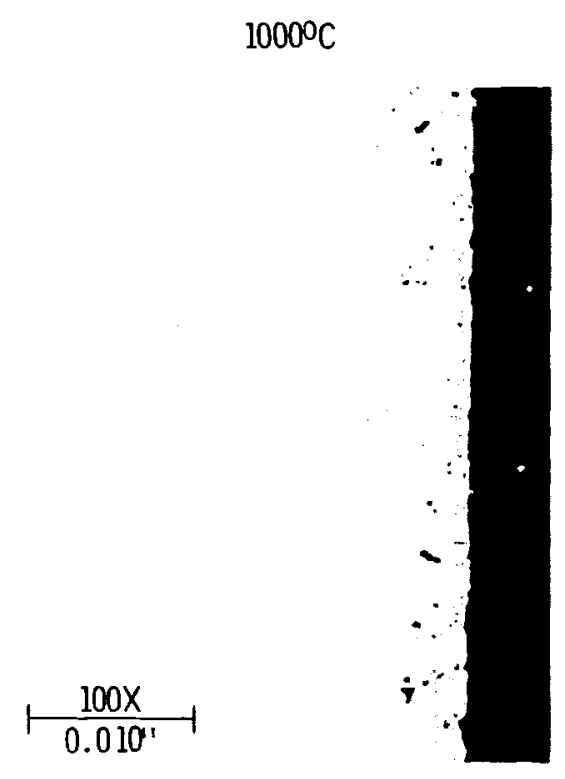

AS-POLISHED

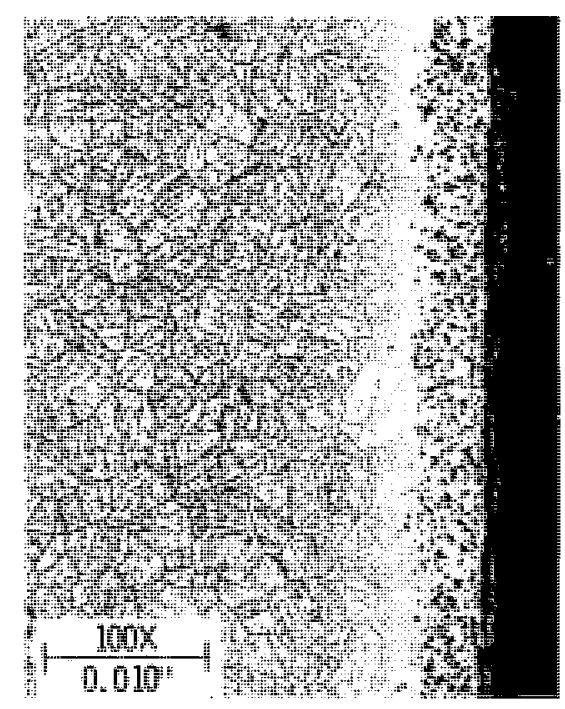

ETCHED

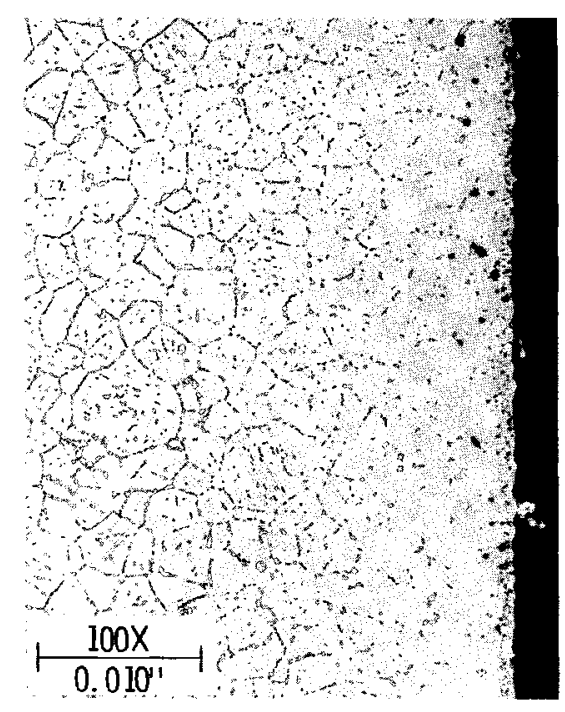

FIGURE 1. Hastelloy $\mathrm{C}-276 \mathrm{Spec}$ imens Exposed to Nonradioactive $\mathrm{SrF}_{2}$ for $12,000 \mathrm{hr}$ Capsule $S / V=0.9 \mathrm{~cm}^{-1}$ 

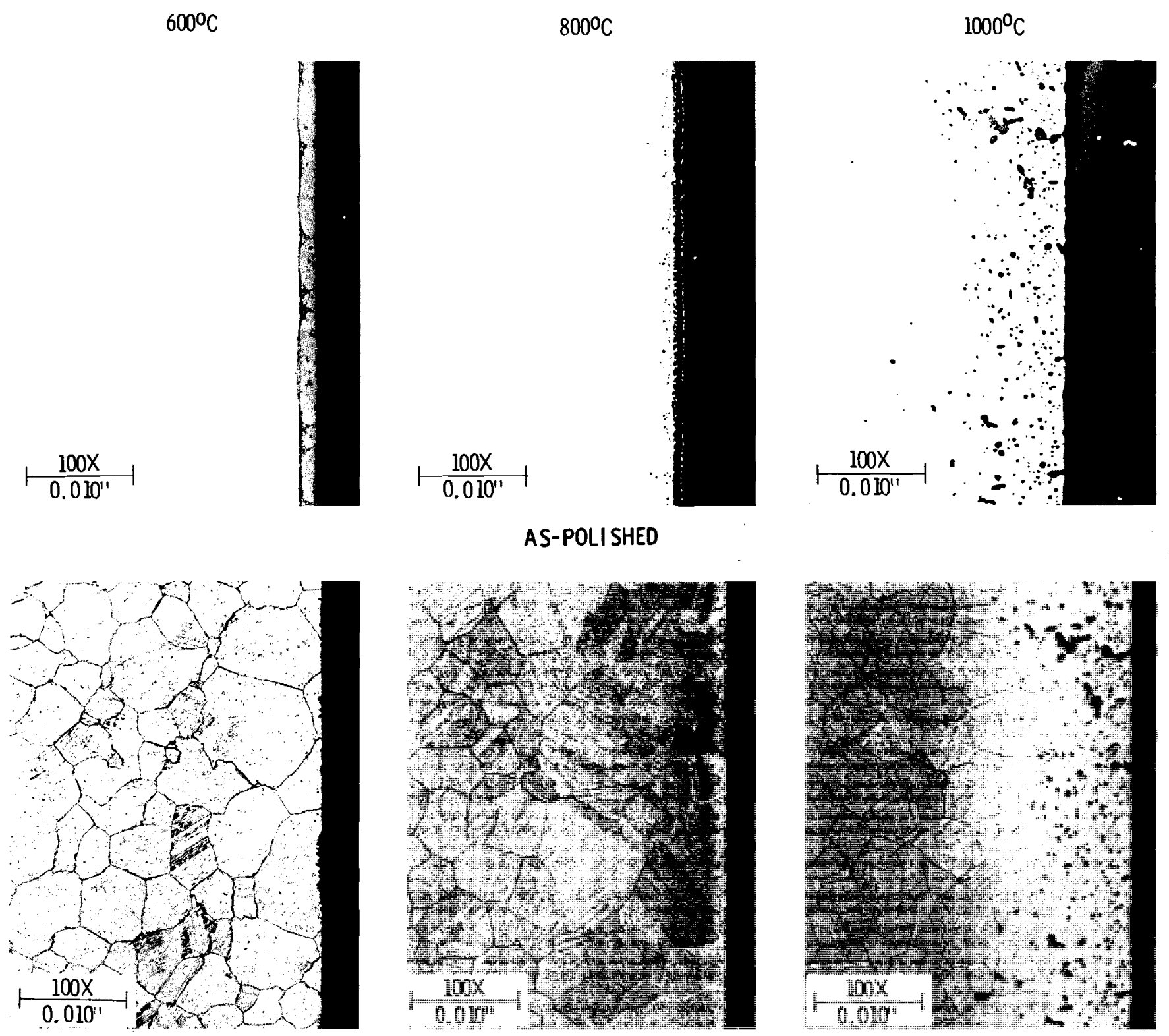

ETCHED

FIGURE 2. Haynes Alloy 25 Specimens Exposed to Nonradioactive $\mathrm{SrF}_{2}$ for $12,000 \mathrm{hr}-$ Capsule $5 / \mathrm{V}=0.9 \mathrm{~cm}^{-1}$ 


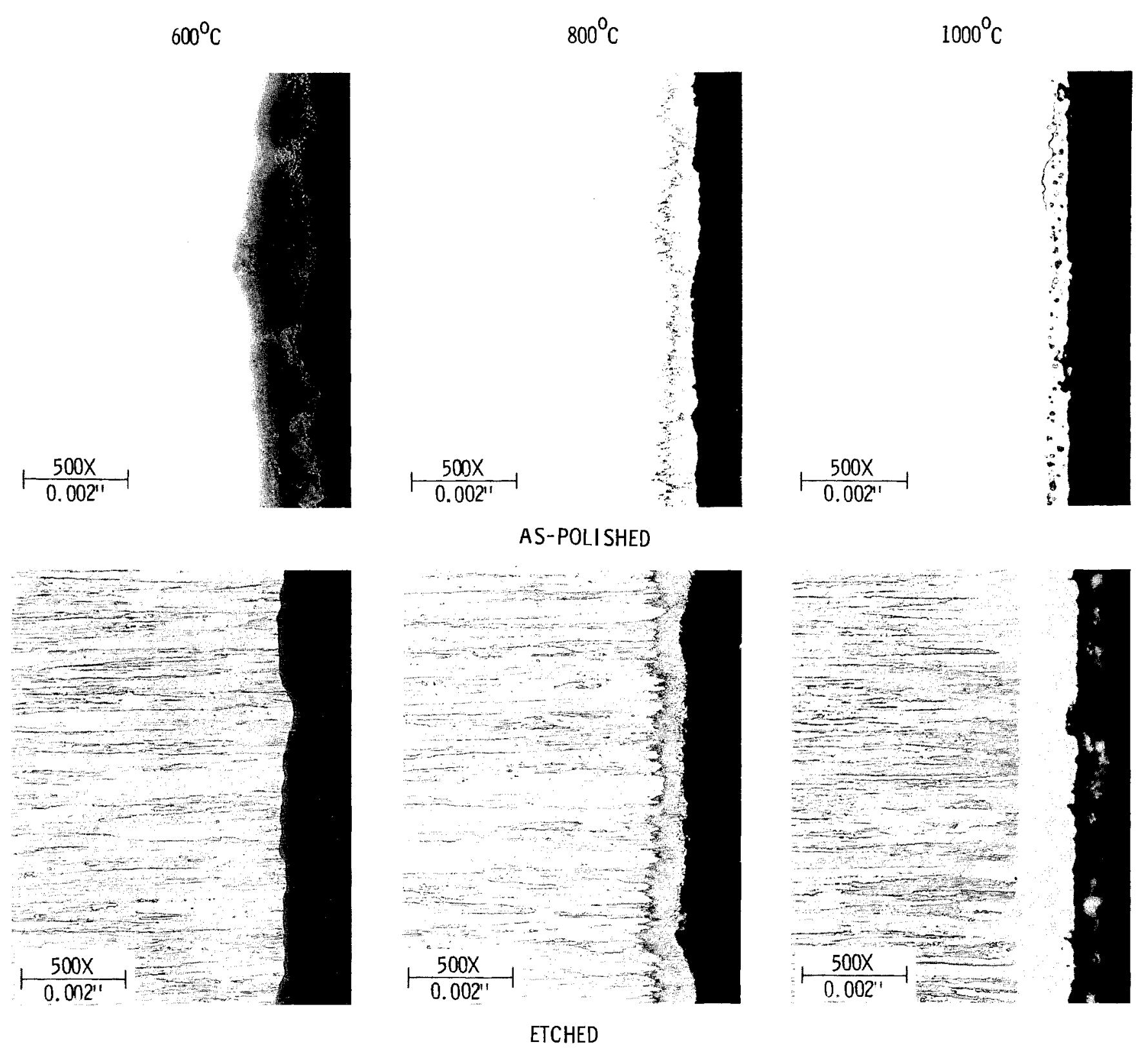
FIGURE 3. TZM Specimens Exposed to Nonradioactive $5 r F 2$ for $12,000 \mathrm{hr}$ -
Capsule $S / V=0.9 \mathrm{~cm}^{-1}$ 


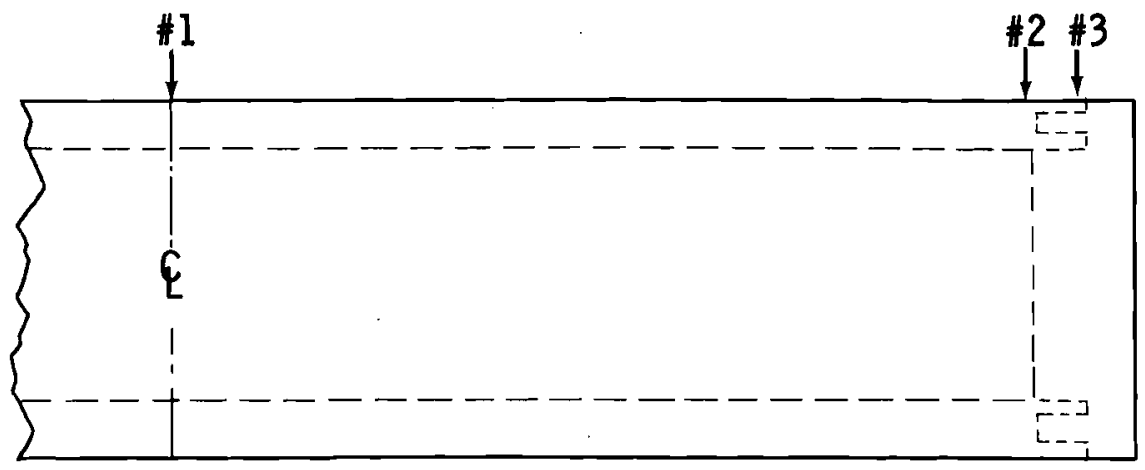

FIGURE 4. Sketch Showing Locations of the Three Puncture Tests on the Stee 1 Stand-In Capsule

sufficient resolution to allow angle-of-strike measurements, and thus will be used for recording subsequent capsule drops. It was also determined that the capsule drop and release mechanism is functioning correctly and will require only slight modification to be ready to use in the upcoming stand-in capsule drops.

Efforts are underway to obtain the Hastelloy $S$ and Hastelloy $C-4$ to be used in fabricating the prototype outer capsule. It is anticipated that the material will be ordered in January, with a planned delivery time of 3 to 4 months.

Oxidation of Hastelloy S and Hastelloy C-4 (H. T. Fullam)

Tests are continuing to measure the rate of oxidation of Hastelloy S and Hastelloy C-4 in air at $600^{\circ}$ to $800^{\circ} \mathrm{C}$. The tests will last up to 10,000 hours. The $7500-h r$ tests have been completed, and examination of the test coupons indicated erratic oxidation behavior of the two alloys. A number of specimens tested for $7500 \mathrm{hr}$ exhibited less weight gain due to oxidation than did corresponding specimens tested for shorter times. None of the coupons showed any evidence of spalling of the oxide layer, and the reason(s) for the erratic behavior has not been determined. Results from the short-term tests (up to 2500 hr) showed that oxidation of the two alloys at $600^{\circ}$ to $800^{\circ} \mathrm{C}$ adhered to parabolic rate relationships; but the longer-term oxidation rates were less than predicted by parabolic rate equations developed from the short-term data. This can be seen by referring to Figures 6 and 7 , in which the oxidation data for the two alloys are plotted as $\Delta \mathrm{m}^{2}\left(\mathrm{mg}^{2} / \mathrm{cm}^{4}\right)$ vs. exposure time in hours. A linear relationship indicates adherence to a parabolic rate relationship. Although the weight gain data indicated erratic oxidation behavior, metallographic examination of the 7500-hr test specimens showed that the oxidation mechanisms were similar to those observed in the short-term tests. Micrographs of specimens from the 7500-hr tests are shown in Figures 8 and 9 .

The tensile specimens from the 5000- and 7500-hr oxidation tests were tension tested at room temperature. Results obtained with the Hastelloy $S$ specimens are presented in Table 2 and Figures 10, 11 and 12, while the Hastelloy $C-4$ results are given in Table 3 and Figures 13, 14 and 15. Evaluation of the test results indicates that oxidation of the two alloys at $600^{\circ} \mathrm{C}$ to $800^{\circ} \mathrm{C}$, for up to $7500 \mathrm{hr}$, has no significant effect on the ir roomtemperature tensile properties. 


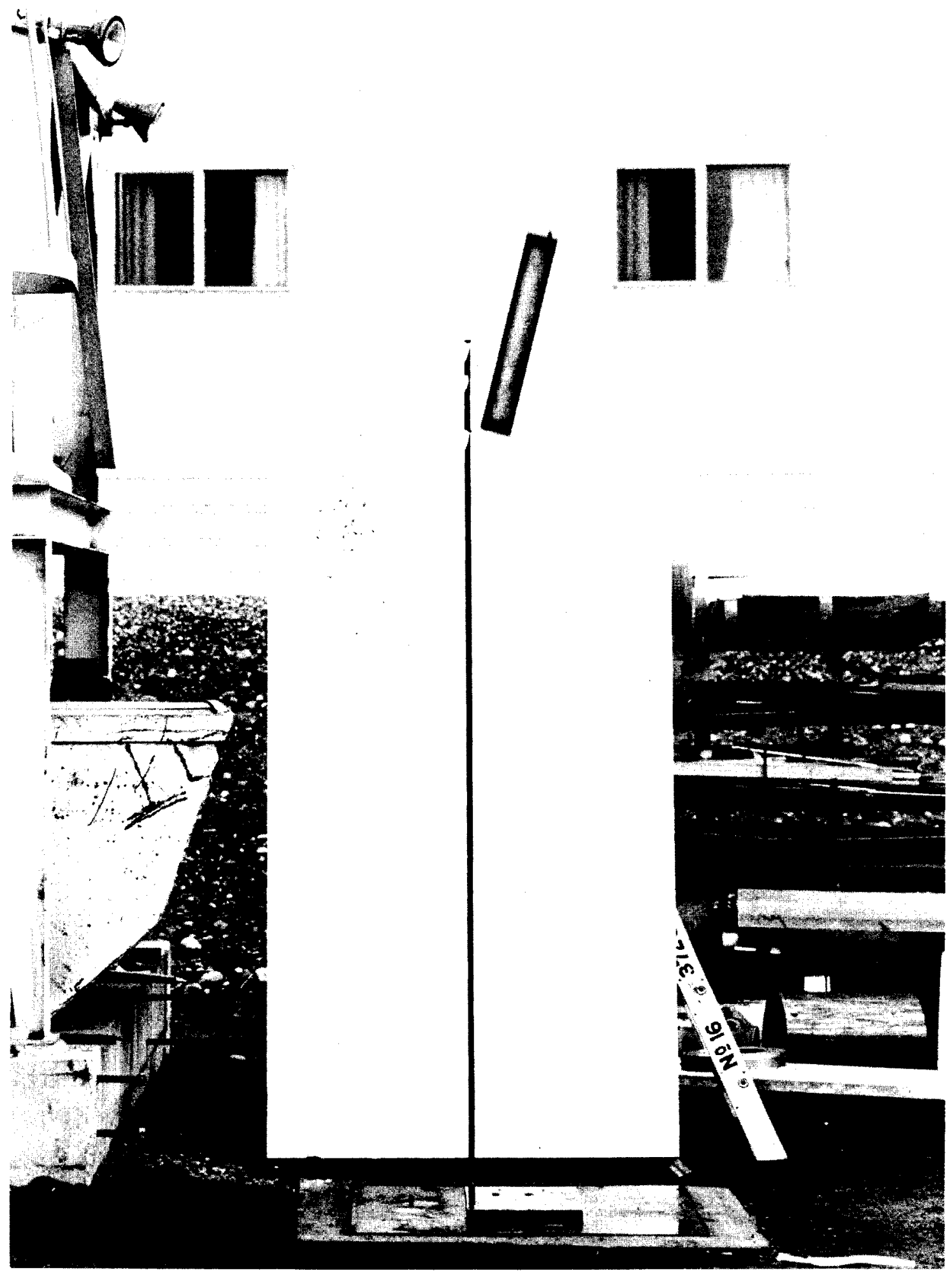

FIGURE 5. Photograph of a 30-Foot Drop Test of an AISI-1018 Steel Capsule 


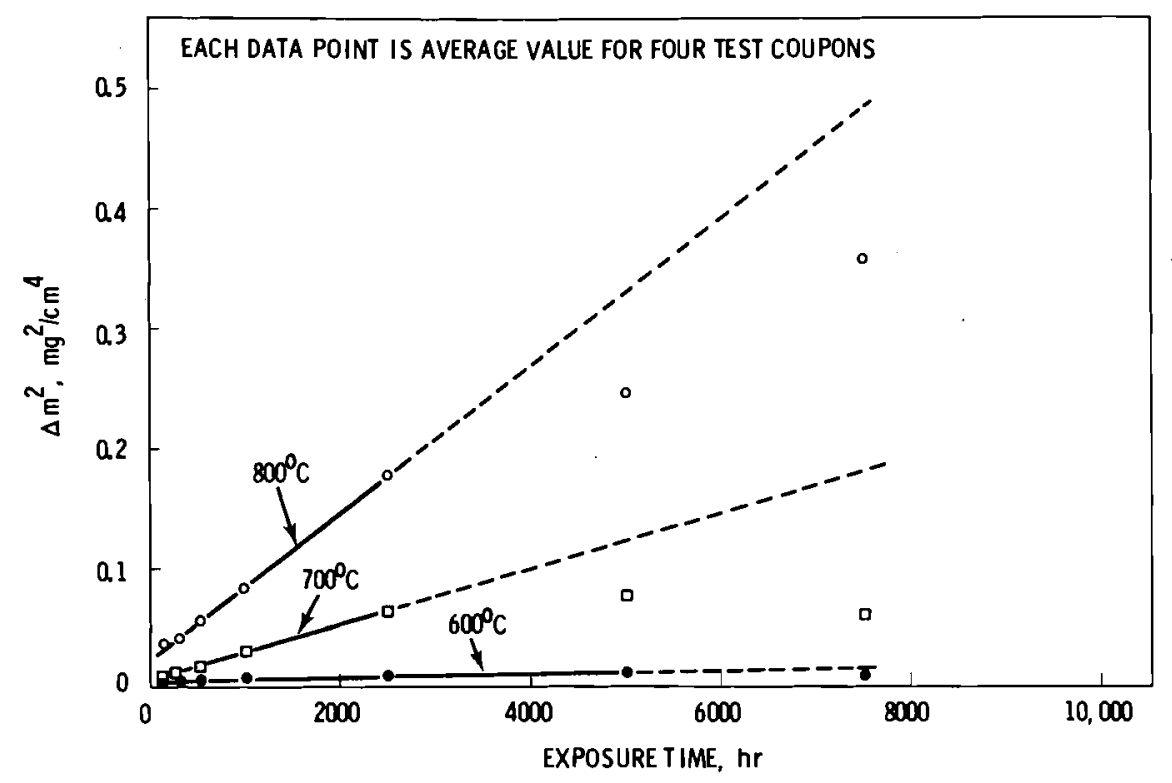

FIGURE 6. 0xidation of Hastelloy $S$ in Air in a Muffle Furnace

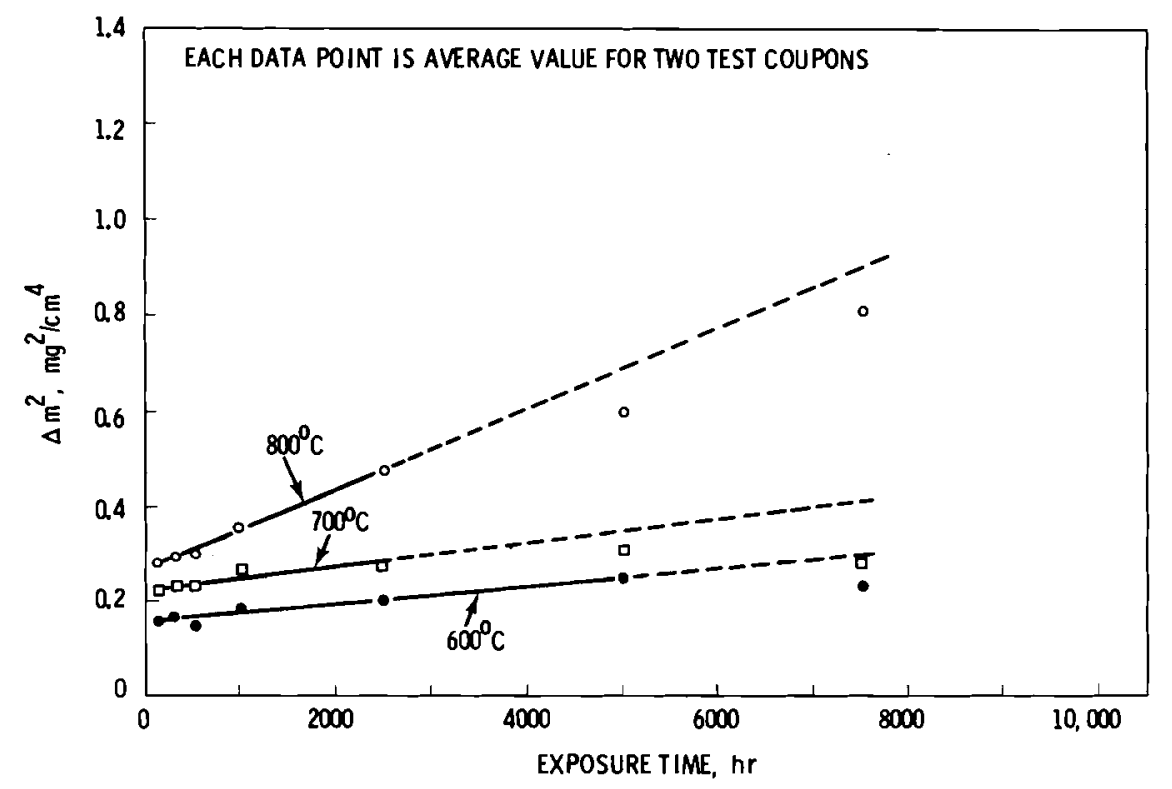

FIGURE 7. Oxidation of Hastelloy C-4 in Air in a Muffle Furnace

Seawater Corrosion of Hastelloy S and Hastelloy C-4 (H. T. Fullam)

The tests to evaluate the resistance of Hastelloy S and Hastelloy C-4 to seawater corrosion are continuing. The 5000-hr tests have been completed, and the test coupons examined. All of the test specimens exhibited some surface discoloration, as shown in Figure 16, but as can be seen in Figures 17 and 18, weight change measurements cont inue to 

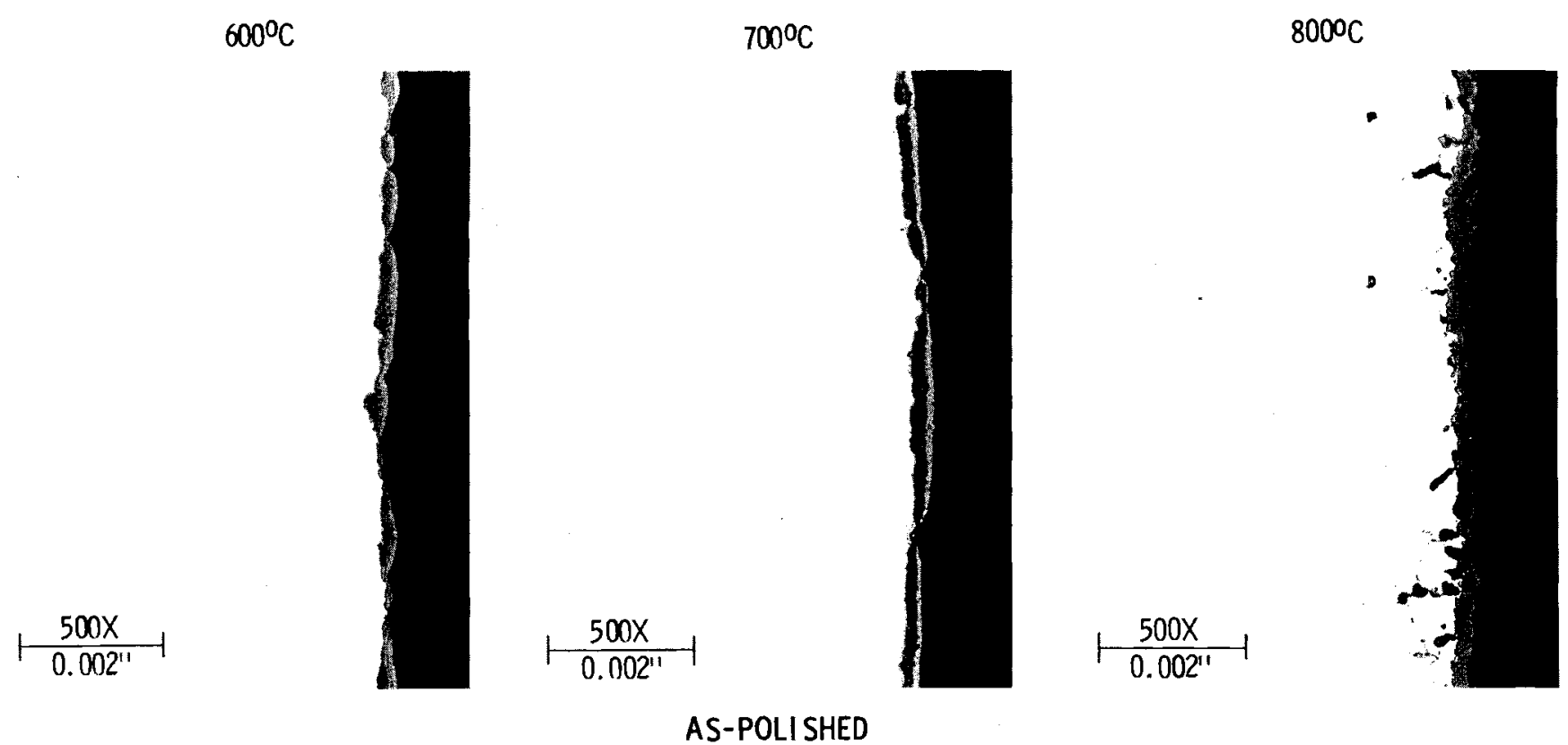

$\infty$
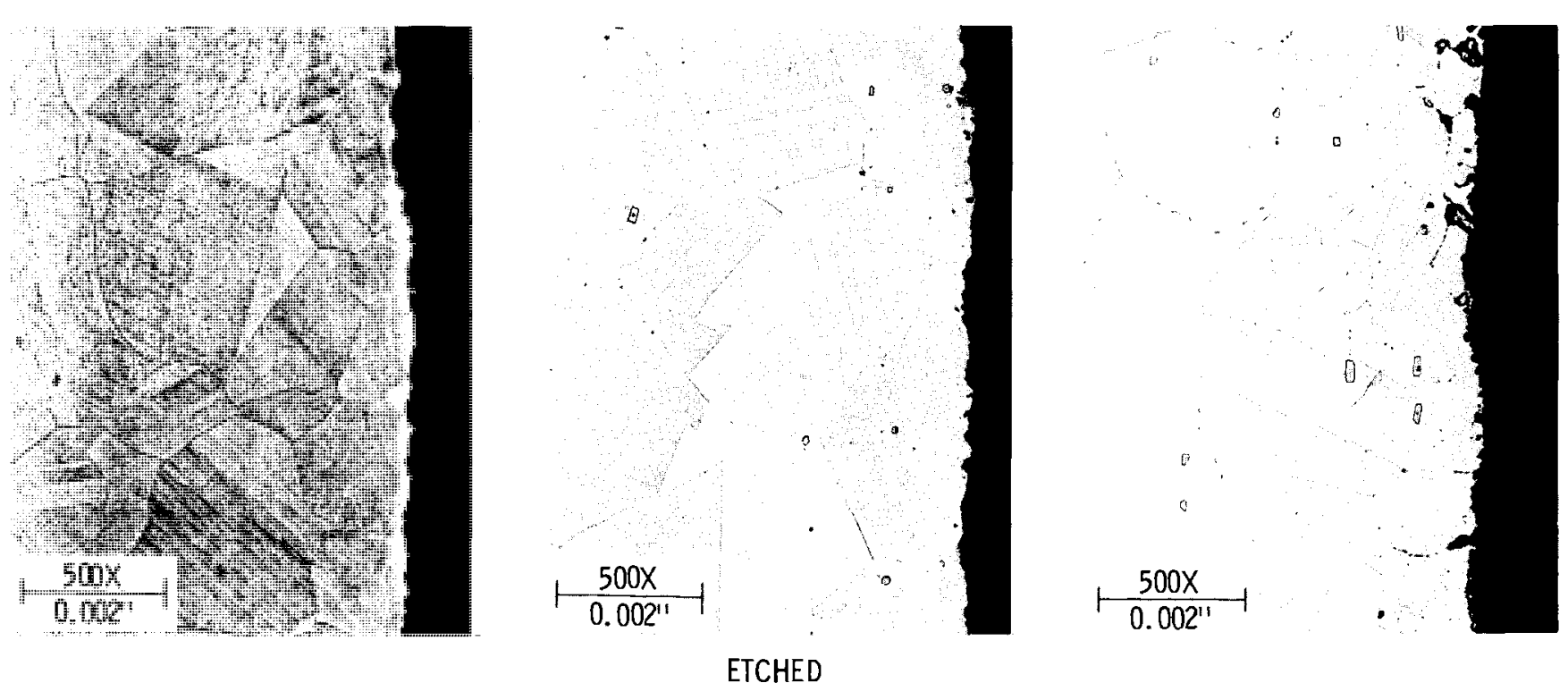

FIGURE 8. Hastelloy S Specimens 0xidized in Air for $7500 \mathrm{hr}$ 

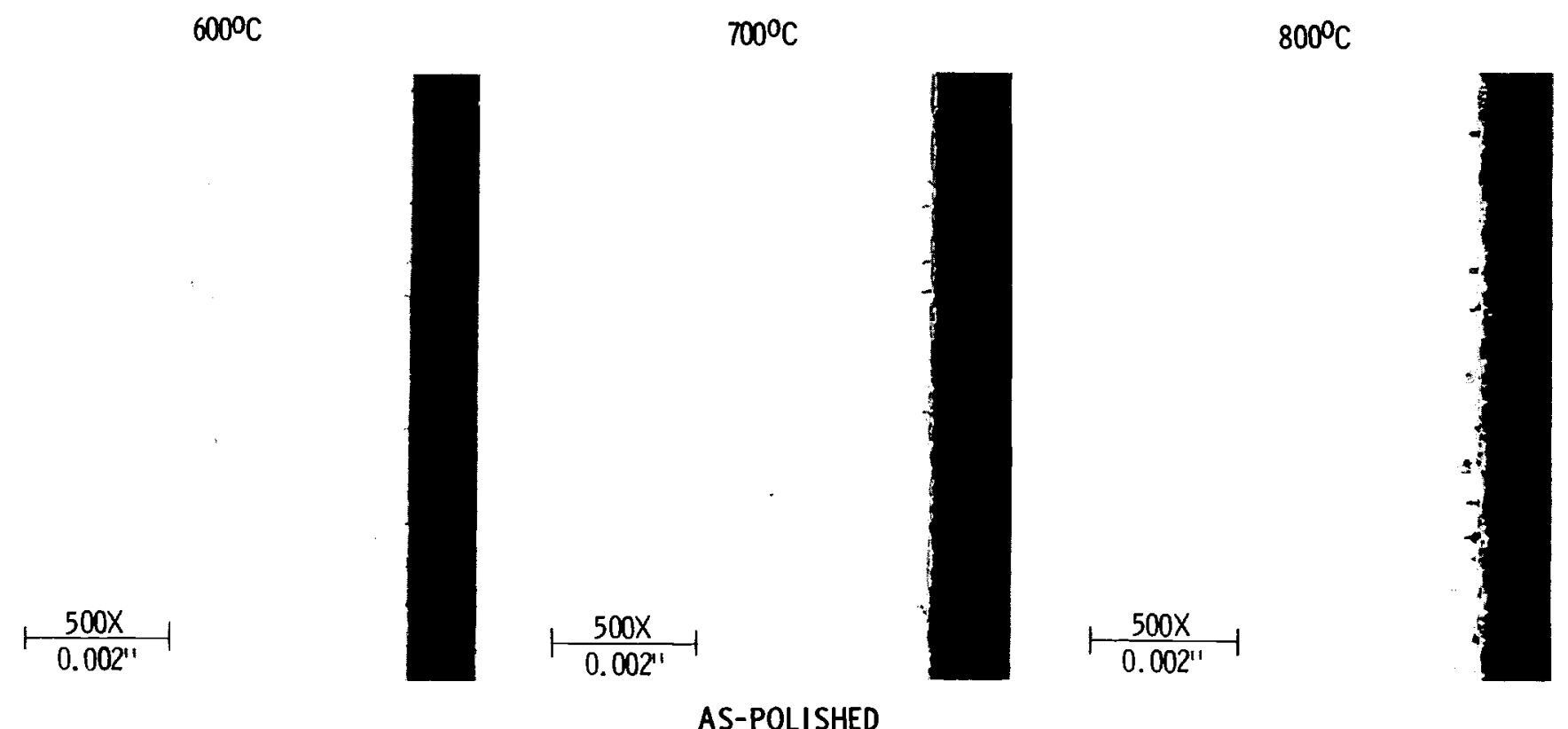

$\overrightarrow{0}$
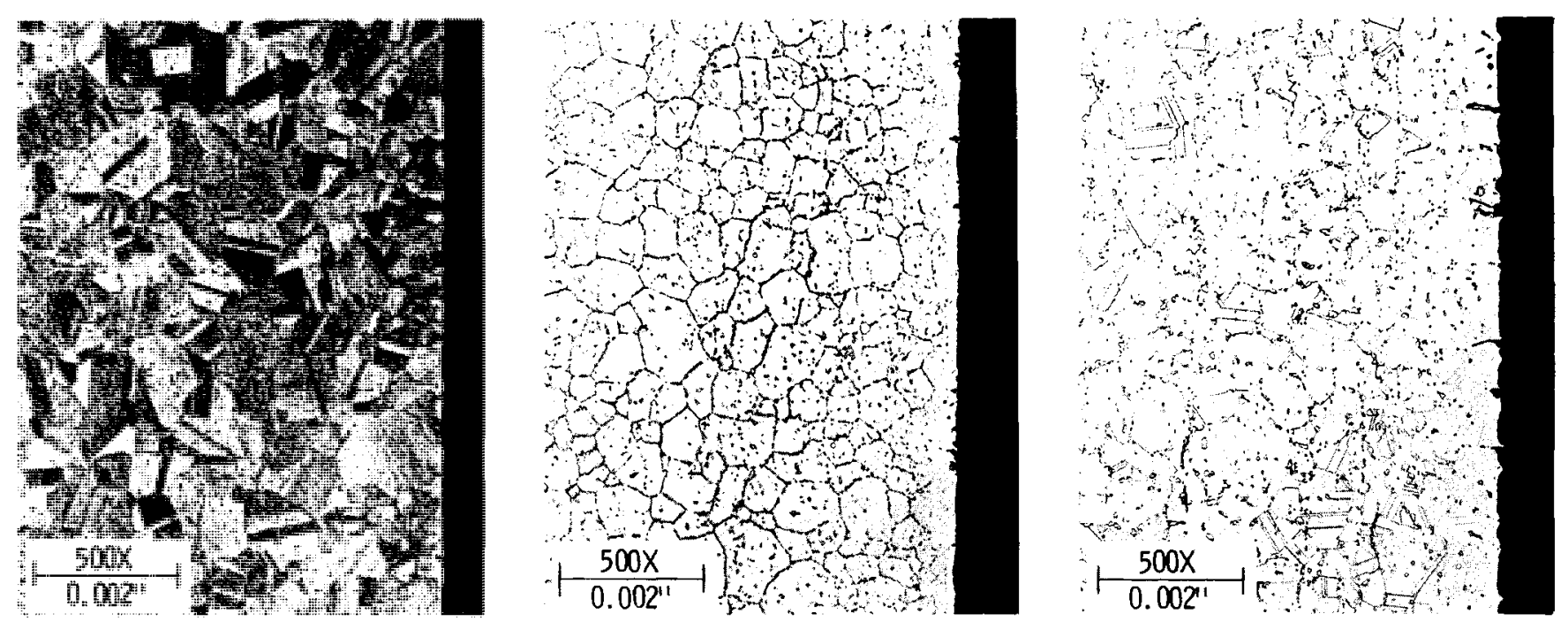

ETCHED

FIGURE 9. Hastelloy C-4 Oxidized in Air in a Muffle Furnace 
TABLE 2. Room-Temperature Tensjle Properties of Hastelloy S Specimens(a) Aged in Air or Vacuum (b) at $600^{\circ} \mathrm{C}, 700^{\circ} \mathrm{C}$, and $800^{\circ} \mathrm{C}$

\begin{tabular}{|c|c|c|c|c|c|c|c|c|c|}
\hline \multirow{2}{*}{ Aging Temp., } & \multirow{2}{*}{$\begin{array}{c}\text { Aging Time, } \\
\mathrm{hr}\end{array}$} & \multirow{2}{*}{\multicolumn{2}{|c|}{$\begin{array}{c}\text { Uitimate } \\
\text { Tensile Strength, } \\
\mathrm{ks} \mathbf{i}\end{array}$}} & \multirow{2}{*}{\multicolumn{2}{|c|}{ 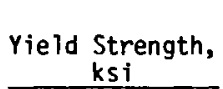 }} & \multicolumn{4}{|c|}{ Elongation, $\%$} \\
\hline & & & & & & \multicolumn{2}{|c|}{ Uniform } & \multicolumn{2}{|c|}{ Tota 7} \\
\hline $\begin{array}{l}\text { (Sol'n Apnealed } \\
\text { Alloy) }\end{array}$ & 0 & \multicolumn{2}{|c|}{$(127.6)$} & \multicolumn{2}{|c|}{$(67.8)$} & \multicolumn{2}{|c|}{$(51.5)$} & \multicolumn{2}{|c|}{$(60.8)$} \\
\hline 600 & 1,000 & 136.0 & 137.9 & 73.1 & 78.4 & 50.4 & 50.8 & 56.0 & 56.1 \\
\hline 600 & 2,500 & 147.8 & 151.2 & 89.5 & 86.7 & 44.3 & 44.4 & 48.8 & 48.3 \\
\hline 600 & 5,000 & 181.6 & 170.5 & 111.9 & 108.5 & 33.6 & 36.5 & 37.1 & 41.4 \\
\hline 600 & 7,500 & 171.5 & 169.1 & 104.8 & 101.5 & 35.8 & 37.8 & 39.8 & 41.0 \\
\hline 600 & 10,000 & & & & & & & & \\
\hline 700 & 1,000 & 131.5 & 127.5 & 67.2 & 64.1 & 53.8 & 55.4 & 60.0 & 61.8 \\
\hline 700 & 2,500 & 127.8 & 128.9 & 61.5 & 66.3 & 55.5 & 47.9 & 62.6 & 54.1 \\
\hline 700 & 5,000 & 134.5 & 132.1 & 69.4 & 68.1 & 47.6 & 48.1 & 53.4 & 53.7 \\
\hline 700 & 7,500 & 130.5 & 129.8 & 65.7 & 62.9 & 50.6 & 50.4 & 57.2 & 57.0 \\
\hline 700 & 10,000 & & & & & & & & \\
\hline 800 & 1,000 & 132.3 & 127.7 & 63.3 & 61.4 & 53.2 & 54.9 & 59.5 & 63.6 \\
\hline 800 & 2,500 & 127.2 & 126.2 & 59.1 & 59.1 & 54.9 & 54.4 & 62.7 & 62.1 \\
\hline 800 & 5,000 & 130.8 & 128.4 & 60.9 & 61.2 & 50.9 & 49.8 & 59.1 & 58.2 \\
\hline 800 & 7,500 & 134.1 & 125.3 & 66.3 & 57.2 & 47.7 & 54.0 & 53.2 & 62.0 \\
\hline 800 & 10,000 & & & & & & & & \\
\hline
\end{tabular}

(a) Four tensile specimens heated in air and 2 tensile specimens heated in vacuum for each set of test conditions.

(b) Tensile specimens heated in evacuated quartz envelopes in the same furnaces as the specimens heated in air.

(c) Solution annealed alloy as received from the vendor.

TABLE 3. Room-Temperture Tensije Properties of Hastelloy C-4 Specimens(a) Aged in Air or Vacuum( ( ) at $600^{\circ} \mathrm{C}, 700^{\circ} \mathrm{C}$, and $800^{\circ} \mathrm{C}$

\begin{tabular}{|c|c|c|c|c|c|c|c|c|c|}
\hline \multirow{3}{*}{$\begin{array}{c}\text { Aging Temp., } \\
{ }_{0} \mathrm{C}\end{array}$} & \multirow{3}{*}{$\begin{array}{c}\text { Aging Time, } \\
\mathrm{hr}\end{array}$} & \multirow{2}{*}{\multicolumn{2}{|c|}{$\begin{array}{c}\text { Ult imate } \\
\text { Tensile Strength, } \\
\text { ksi }\end{array}$}} & \multirow{2}{*}{\multicolumn{2}{|c|}{$\underset{\text { Yield }}{\substack{\text { Strength } \\
\text { ks }}}$}} & \multicolumn{4}{|c|}{ Elongation, $\%$} \\
\hline & & & & & & & & & \\
\hline & & Vacuum & Air & Vacuum & Air & Vacuum & Air & Vacuum & Air \\
\hline $\begin{array}{l}\text { (Sol'n Apnealed } \\
\text { Alloy) (C) }\end{array}$ & & & & & & $(60$ & & & \\
\hline 600 & 2,500 & 182.3 & 179.3 & 103.6 & 99.1 & 38.7 & 42.0 & 43.6 & 48.6 \\
\hline 600 & 5,000 & 179.9 & 180.3 & 102.1 & 106.7 & 39.3 & 41.2 & 46.5 & 46.2 \\
\hline 600 & 7,500 & 178.3 & 178.4 & 104.3 & 101.6 & 41.2 & 39.5 & 47.4 & 45.1 \\
\hline 600 & 10,000 & & & & & & & & \\
\hline 700 & 2,500 & 152.9 & 119.0 & 60.8 & 54.0 & 55.3 & 63.9 & 61.6 & 64.1 \\
\hline 700 & 5,000 & 123.2 & 122.2 & 55.7 & 55.9 & 58.7 & 63.3 & 65.6 & 72.7 \\
\hline 700 & 7,500 & 125.7 & 126.7 & 58.0 & 57.5 & 58.9 & 58.3 & 66.3 & 66.2 \\
\hline 700 & 10,000 & & & & & & & & \\
\hline 800 & 2,500 & 115.2 & 116.1 & 48.5 & 49.7 & 63.8 & 63.2 & 68.1 & 72.3 \\
\hline 800 & 5,000 & 120.2 & 118.6 & 51.9 & 50.4 & 60.1 & 59.6 & 69.5 & 67.4 \\
\hline 800 & 7,500 & 120.2 & 119.3 & 49.7 & 50.3 & 62.9 & 60.7 & 71.7 & 68.7 \\
\hline 800 & 10,000 & & & & & & & & \\
\hline
\end{tabular}

(a) Dupiicate specimens tested at each set of conditions.

(b) Specimens heated in evacuated quartz envelopes in the same furnaces as the specimens heated in air. (c) Solution annealed alloy as received from the vendor. 


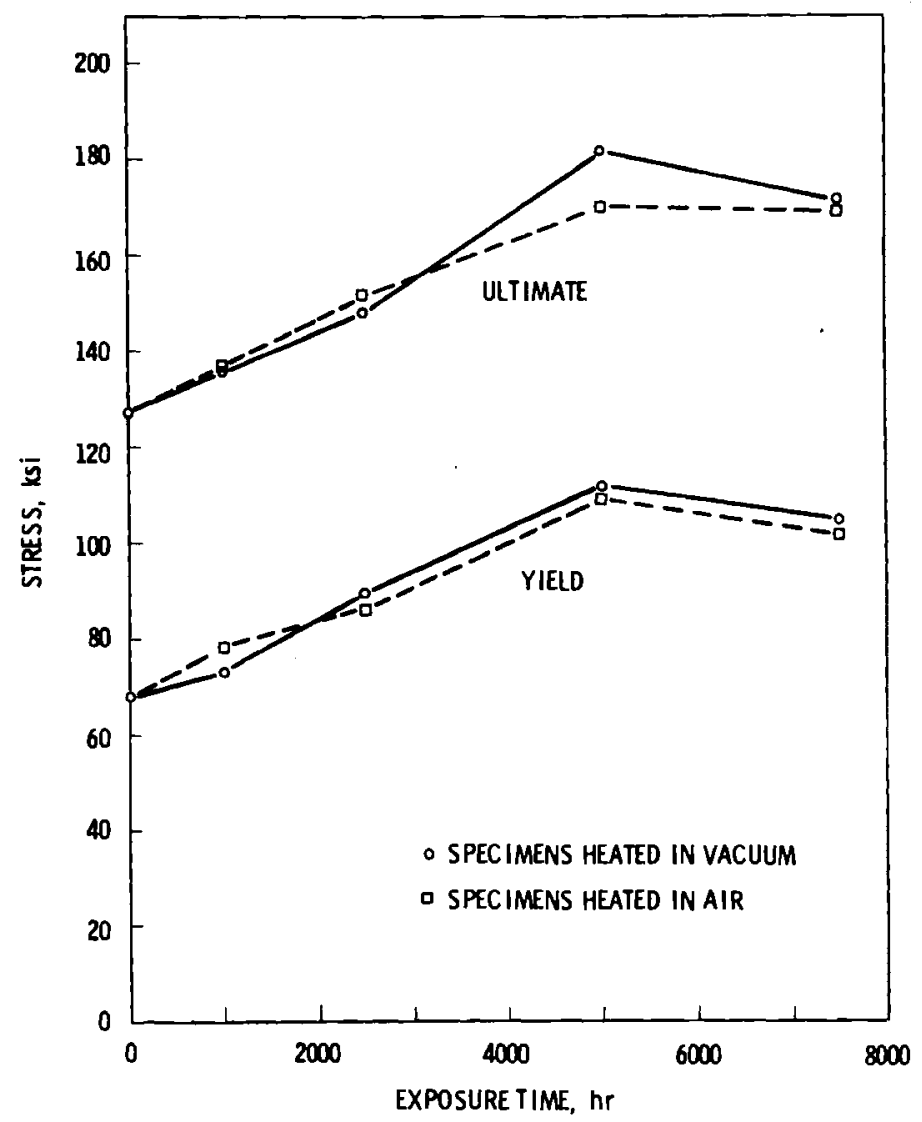

FIGURE 10. Room-Temperature Tensile Properties of Hastelloy $S$ Aged in Air or Vaccum at $600^{\circ} \mathrm{C}$

indicate only very slight corrosion. Corrosion of the Hastelloy $\mathrm{C}-4$ coupons was much greater than corrosion of the Hastelloy $S$ coupons ( 4 to $5 x$ ), but it was still very low. If one assumes uniform surface corrosion, the average Hastelloy $C-4$ specimen weight loss after $5000 \mathrm{hr}$ exposure corresponds to a corrosion rate of about $0.4 \mu \mathrm{m} / \mathrm{yr}\left(1.5 \times 10^{-5} \mathrm{in} . / \mathrm{yr}\right)$. Since the corrosion is not uniform, the depth of metal affected by seawater attack would be greater than the calculated average corrosion rate, but should still be low. Metallographic examination of the coupons from the $5000-h r$ tests provided no visual evidence of corrosion of the two alloys by the seawater. Microscopic examination of prestressed specimens from the 5000-hr tests showed no evidence of stress-corrosion cracking of either alloy.

Tensile specimens from the 5000-hr tests were tension tested at room temperature. The results obtained are presented in Table 4. Evaluation of the data shows that the roomtemperature tensile properties of the two alloys are unaffected by exposure to flowing seawater for $t$ imes of up to 5000 hours. 


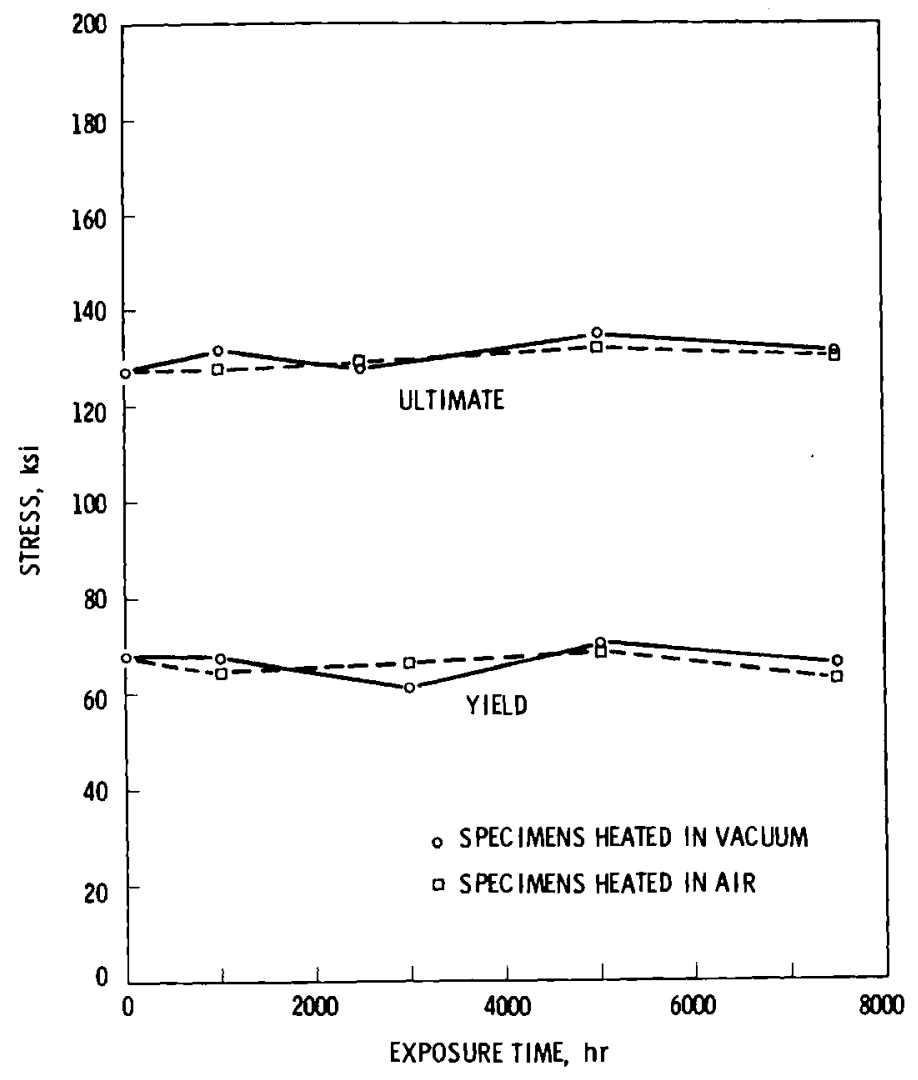

FIGURE 11. Room-Temperature Tensile Properties of Hastelloy $S$ Aged in Air or vacuum at $700^{\circ} \mathrm{C}$

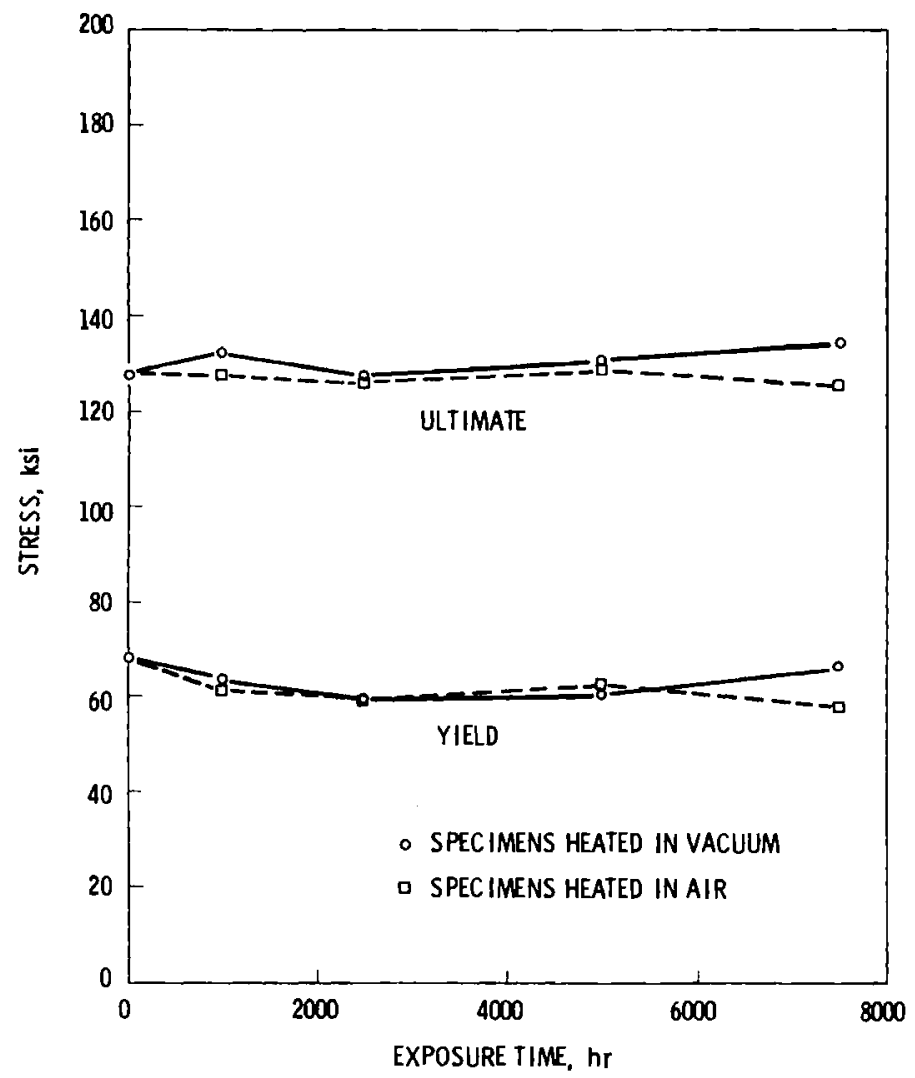

FIGURE 12. Room-Temperature Tensile Properties of Hastelloy S Aged in Air or Vacuum at $800^{\circ} \mathrm{C}$ 

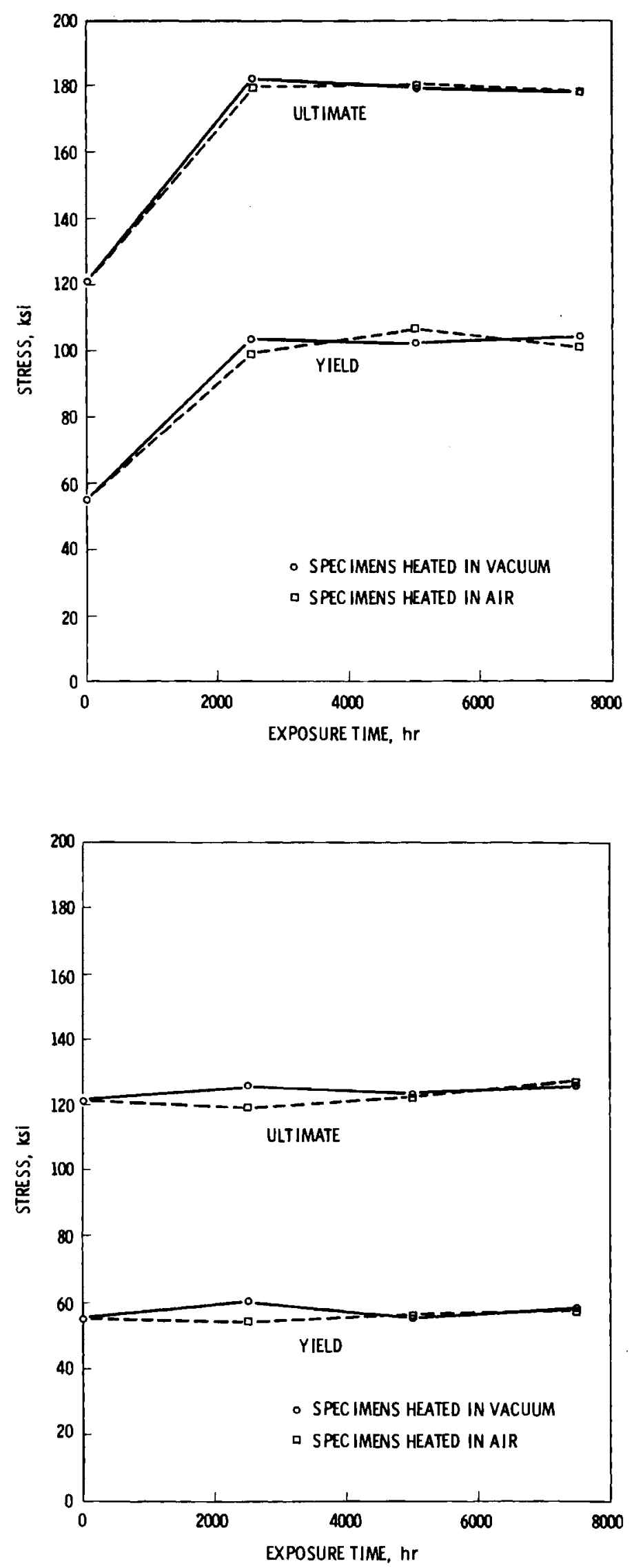

FIGURE 13. Room-Temperature Tensile Properties of Hastelloy C-4 Aged in Air or vacuum at $600^{\circ} \mathrm{C}$
FIGURE 14. Room-Temperature Tensile Properties of Hastelloy C-4 Aged in Air or vacuum at $700^{\circ} \mathrm{C}$ 


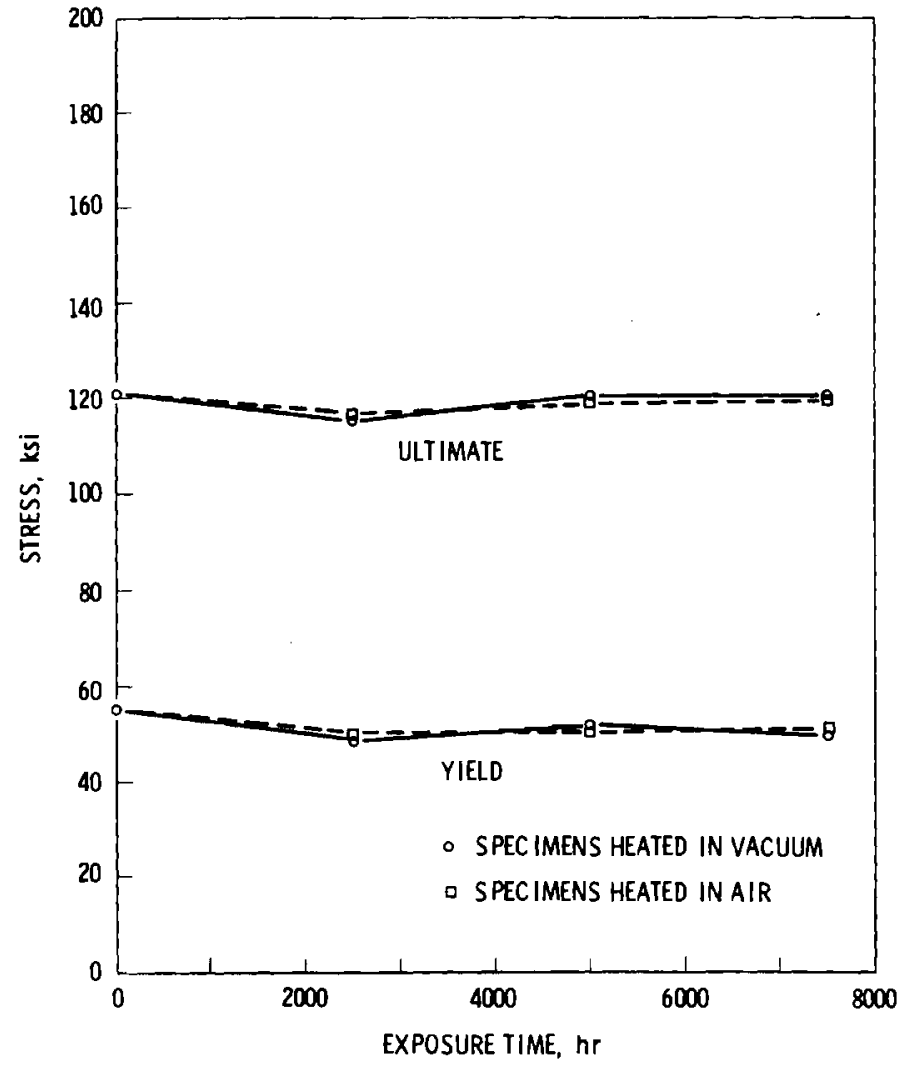

FIGURE 15. Room-Temperature Tensile Properties of Hastelloy C-4 Aged in Air or vacuum at $800^{\circ} \mathrm{C}$ 

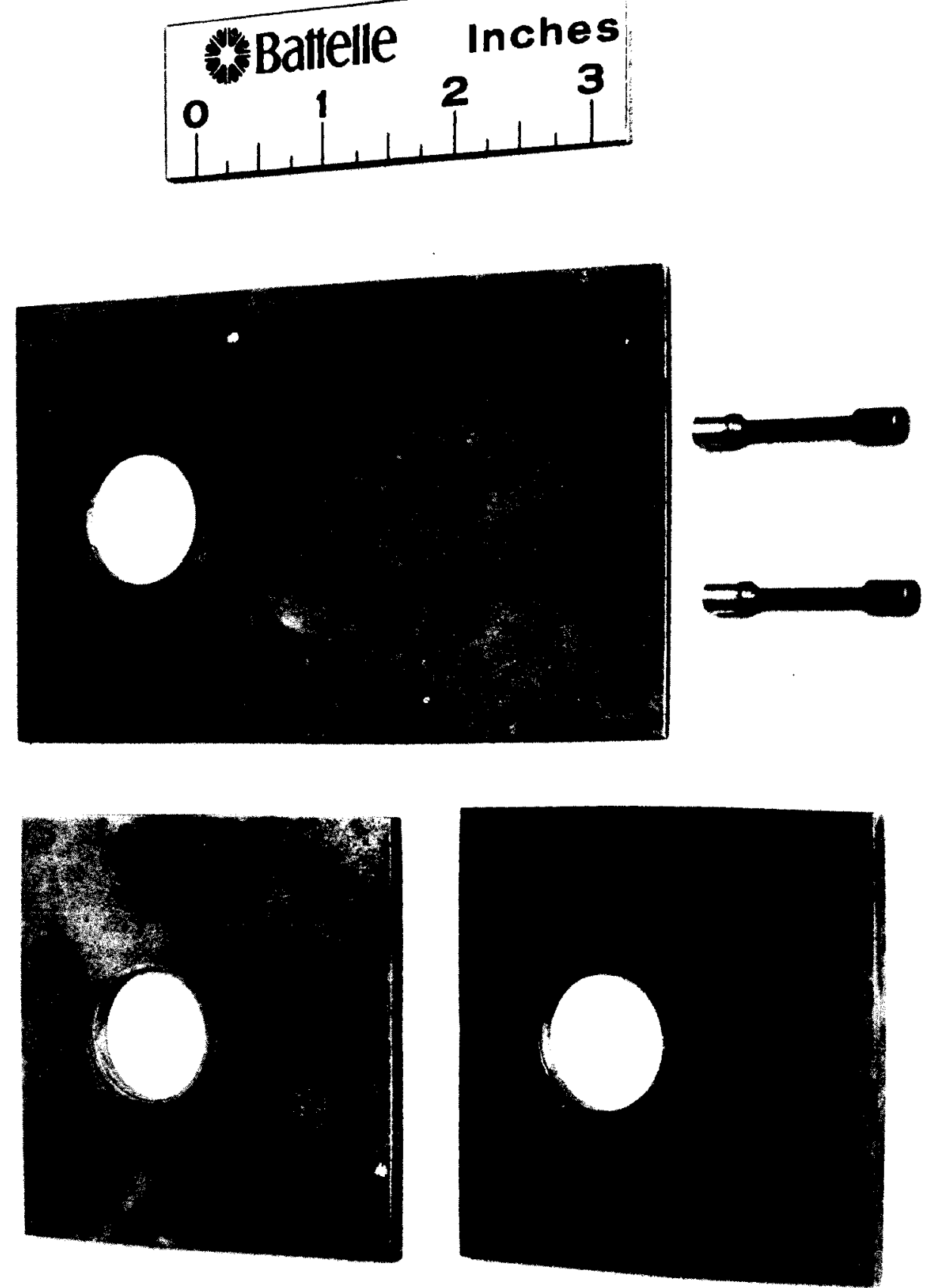

FIGURE 16. Hastelloy $S$ and Hastelloy C-4 Test Coupons, Including Tensile Specimens, Exposed to Flowing Natural Seawater for $5000 \mathrm{hr}$ 

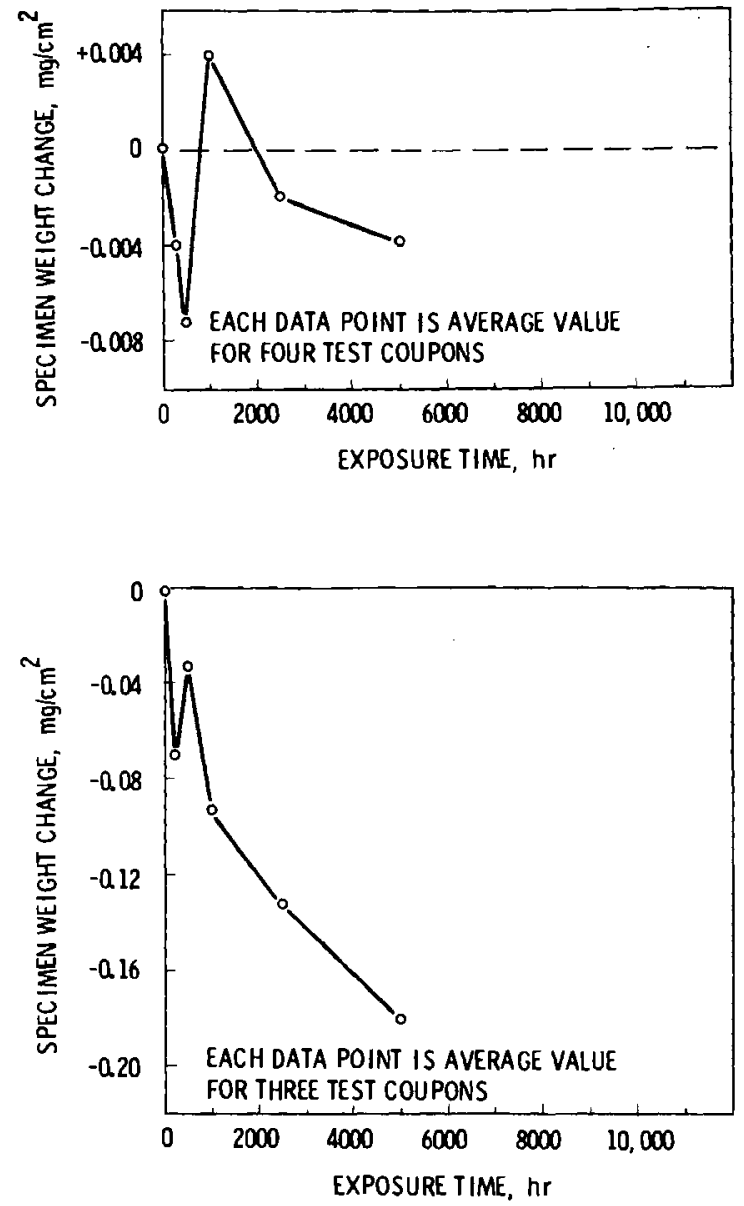

FIGURE 17. Corrosion of Hastelloy $S$ in Flowing Natural Seawater at Amb ient Temperature
FIGURE 18. Corrosion of Hastelloy $\mathrm{C}-4$ in Flowing Natural Seawater at Ambient Temperature

TABLE 4. Room-Temperature Tensile Properties of Hastelloy S and Hastelloy C-4 Specimens (a) Exposed to Flowing Natural Seawater at Ambient Temperature

\begin{tabular}{|c|c|c|c|c|c|}
\hline Material & $\begin{array}{c}\text { Exposure Time, } \\
\mathrm{hr}\end{array}$ & $\begin{array}{c}\text { Uit imate Tensile } \\
\text { Strength, } \\
\text { ksi }\end{array}$ & $\begin{array}{c}\text { Yield Strength, } \\
\mathrm{ksi}\end{array}$ & $\frac{\text { Elonga }}{\text { Uniform }}$ & $\frac{\text { ion, } \%}{\text { Total }}$ \\
\hline \multirow[t]{6}{*}{ Hastelloy S } & $\begin{array}{l}\text { (Sol'n Annealed } \\
\text { Alloy) }\end{array}$ & $(127.6)$ & $(67.8)$ & $(51.5)$ & $(60.8)$ \\
\hline & 1,000 & 129.0 & 70.6 & 53.3 & 61.7 \\
\hline & 2,500 & 126.5 & 69.5 & 53.2 & 62.1 \\
\hline & 5,000 & 127.4 & 68.0 & 51.3 & 61.1 \\
\hline & 7,500 & & & & \\
\hline & 10,000 & & & & \\
\hline \multirow[t]{6}{*}{ Hastelloy C-4 } & $\begin{array}{l}\text { (Sol'n Apnea led } \\
\text { Alloy) }\end{array}$ & $(121.0)$ & $(55.0)$ & $(60.9)$ & $(71.5)$ \\
\hline & 1,000 & 123.7 & 56.5 & 59.7 & 69.7 \\
\hline & 2,500 & 120.5 & 53.1 & 58.9 & 69.1 \\
\hline & 5,000 & 120.8 & 52.9 & 59.3 & 69.5 \\
\hline & 7,500 & & & & \\
\hline & 10,000 & & & & \\
\hline
\end{tabular}

(a) Four tensile specimens of each alloy tested for each time period and average values reported.

(b) Solution annealed alloy as received from the vendor. 


\section{DISTRIBUTION}

No. of

Copies

\section{OFFSITE}

A. A. Churm

DOE Patent Division

9800 S. Cass Avenue

Argonne, IL 60439

T. A. Dillon

DOE Advanced Systems and Materials Production Division

Washington, DC 20545

T. J. Dobry, Jr.

DOE Advanced Systems and Materials Production Division

Washington, DC 20545

T. J. Holleman

DOE Advanced Systems and Materials Production Division

Washington, DC 20545

A. P. Litman

DOE Advanced Systems and Materials Production Division

Washington, OC 20545

J. J. Lomb ardo

DOE Advanced Systems and Materials Production Division

Washington, OC 20545

3 W. C. Remini

DOE Advanced Systems and Materials Production Division

Washington, DC 20545

B. J. Rock

DOE Advanced Systems and Materials Production Division

Washington, DC 20545

N. R. Thielke

DOE Advanced Systems and Materials Production Division

Washington, DC 20545

\section{J. M. Maddox}

DOE

E201

Washington, OC 20545

C. A. Cooley

DOE Waste Management Division

Washington, DC 20545
No. of

Copies

D. C. Davis, Jr.

DOE Oak Ridge Operations Office

P. 0. BoX E

Oak Ridge, TN 37830

W. T. Goidston

DOE Savannah River Operations Office

P.0. Box A

Aiken, SC 29801

27 DOE Technical Information Center

C. A. Alexander

Battelle Columbus Laboratories

$505 \mathrm{King}$ Avenue

Columbus, $\mathrm{OH} 43201$

W. R. Pardue

Battelle Columbus Laboratories

505 King Avenue

Columbus, $\mathrm{OH} 43201$

W. J. Zielenback

Battelle Columbus Laboratories

505 King Avenue

Columbus, $\mathrm{OH} 43201$

R. T. Huntoon

E. I. duPont deNemours and Company

Savannah River Laboratory

Aiken, SC 29801

E. H. Cooke-Yarborough

Electronics and Applied Physics Division

Building 347.3 , AERE Harwe 11

Oxfordshire OX11 ORA

GREAT BRITAIN

H. C. Carney

General Atomic Company

P.0. Box 81601

San Diego, CA 92138

P. E. Brown

General Electric Company MSVD

P.0. Box 8555

Philadelphia, PA 19101

G. E. Robinson

Genera? Electric Company

Vallecitos Laboratory

P.0. Box 846

Pleasanton, CA 94566 
No. of

Copies

S. E. Bronisz

LoS Alamos Scientific Laboratory

P.0. Box 1663

Los Alamos, NM 87544

R. A. Kent

Los Alamos Scientific Laboratory

P.0. Box 1663

LoS Alamos, NM 87544

R. N. R. Mulford

LoS Alamos Scientific Laboratory

P.0. Box 1663

Los Alamos, NM 87544

W. T. Cave

Mons anto Research Corporation

Mount Laboratory (DOE)

Nuc lear Operations

P.0. Box 32

Miamisburg, $\mathrm{OH} 45342$

R. Dewitt

Mons anto Research Corporation

Mount Laboratory (DOE)

Nuc lear Operations

P.0. Box 32

Miamisburg, $\mathrm{OH} 45342$

Department of the Army

Headquarters, U.S. Army

Facilities Engineering Support Agency

Ford Belvoir, VA 22060

H. H. Musselman, Tech. Dir.

Officer in Charge

Lt. J. H. Vogt

Nava 1 Nuclear Power Unit

Code 70

Port Hueneme, CA 93043

2 A. A. Arcuni

Naval Facilities Engineering Command

Office of Special Assistant Nuc lear Programs (O4N)

200 Stovall Street

Alexandria, VA 22332

F. N. Case

Oak Ridge National Laboratory

Oak Ridge, TN 37830

R. S. Crouse

Oak Ridge National Laboratory

Oak Ridge, TN 37830
No. of

Copies

K. W. Haff

Oak Ridge National Laboratory

Oak Ridge, TN 37830

J. Hammond

Oak Ridge National Laboratory

Oak Ridge, TN 37830

J. R. Keiser

Oak Ridge National Laboratory

Oak Ridge, TN 37830

E. Lamb

Oak Ridge National Laboratory

Oak Ridge, TN 37830

C. L. Ott inger

Oak Ridge National Laboratory

Oak Ridge, TN 37830

J. C. Posey

Oak Ridge National Laboratory

Oak Ridge, TN 37830

A. C. Schaffhauser

Oak Ridge National Laboratory

Oak Ridge, TN 37830

P. Dick

Teledyne Energy Systems

$110 \mathrm{~W}$. Timonium Road

Timon ium, MD 21093

R. Hannah

Teledyne Energy Systems

110 W. Timonium Road

Timon ium, MD 21093

W. A. McDonald

Teledyne Energy Systems

110 W. Timonium Road

Timon ium, MD 21093

P. Vogelberger

Teledyne Energy Systems

$110 \mathrm{~W}$. Timonium Road

Timonium, MD 21093

C. C. Silverste in West inghouse Astronuc lear Laboratory

P.0. Box 10864

Pittsburgh, PA 15236 
No. of

Copies

\section{ONSITE}

3 DOE Richland Operations

W. A. Burns

W. C. Johnson

H. E. Ransom

8 Rockwe 11 Hanford Operations

L. I. Brecke

W. R. Chr istensen

H. H. Hopk ins

J. D. Kaser

E. J. Kosiancic

T. H. May

D. Ramey

J. P. Sloughter

23 Pacific Northwest Laboratory

D. G. Atteridge

H. T. Fullam (3)

M. H. Henry (3)

J. H. Jarrett

R. P. Marshall

R. E. Nightingale

N. J. Olson

L. D. Perrigo

A. M. Platt

W. E. Sande

F. A. Simonen

H. H. Van Tuyl

Technical Files (5)

Publishing Coordination (2) 